\title{
The relationship between Social Capital and Ethics: An Application at Health Sector
}

\author{
Ozgur DEMIRTAS \\ Department of Management, Turkish Air Force Academy \\ Kayseri, TURKEY \\ E-mail: demirtasozgur@yahoo.com \\ Abdurrahim EMHAN (Corresponding author) \\ Department of Management, Selahaddin Eyyubi University \\ Diyarbakır, TURKEY \\ E-mail: aemhan@gmail.com
}

Received: May 30, 2015 Accepted: July 17, 2015 Published: August 24, 2015

doi:10.5296/jpmr.v1i1.8019 URL: http://dx.doi.org/10.5296/jpmr.v1i1.8019

\begin{abstract}
In this study, we examined a relationship between social capital and ethics. For this aim, a questionnaire form, which consists of 35-item, was used out of some demographic variables. The survey was gathered from 339 hospital employees' who are working at governmental and private hospitals. The results indicated that there was a significant positive relationship between social capital and ethics. In addition we found that nurses reported more scores on ethics, and employees working at private sector reported more ethical scores than government employees. Further, several significant differences have been identified according to some demographic variables.
\end{abstract}

Keywords: Social Capital, Ethics, Health Sector

\section{Introduction}

Ethics has become an important issue among academicians and practitioners due to the ethical scandals such as Enron and Dupont (Demirtas, 2015). Thus, in the organizational context much of the studies have taken into the consideration of ethical concept. As noted by 
Crane (1999), there is a lack of high quality empirical research in the business ethics literature.

The ethics is conceptualized as a way of living. A historically contextualized ethics, therefore, exists in all eras. Taking this debate into the present day, it is clear that there is no necessary separation between the world of work and the way of living one's life (Spence \& Rutherfoord, 2003). Thus, from an organizational context, relationships between individuals and organizations should be thought as ethical or not-ethical.

The ethical behaviors are mostly important in health sector. Because, from the beginning of their working career, health sector personnel are expected to behave ethically as in their organizational or in their daily life. Because, from a social learning theory (Bandura, 1977), nurses are mostly expected to behave ethically as a role model (Bandman \& Bandman, 2002; Clarke, 1991; MacDonald, 2006; Olson, 1994; Tuckett, 2005). Because, nurses are ideally placed to drive the safety and quality agenda within health care because of their unique proximity to patients (Richardson \& Storr, 2010).

As indicated by Spence and Rutherfoord (2003), one critical common factor that emerges within the ethical concept is social capital. Because, in today's highly dynamic changing environment, social capital has been emphasized to be a key concept in the ethical context (Spence, Jeurissen \& Rutherfoord, 2000). In the literature review, there are varied definitions associated with social capital (see Adler \& Kwon, 2002; Paldam, 2000). This concept is defined as "the goodwill available to individuals/groups, and its sources lie in the structure and content of the actor's social relations. Its effects flow from the information, influence, and solidarity it makes available to the actor (Adler \& Kwon, 2002, p.23). They consider goodwill to be "the sympathy, trust and forgiveness offered us by friends and acquaintances" (p.18). In addition, Paldam (2000) emphasized that social capital is mostly associated with the relationships among individuals and organizations, and the norms of reciprocity and trustworthiness that arise from these relations. Thus, from a social relationship context, Spence and Rutherfoord (2003) have taken the ethical concept and social capital together. They indicate that these concepts often expose practices of exchange, reciprocity, and goodwill.

Social capital has many utilities for organizations/communities. It promotes networking among individuals, and faster information flows (Putnam, 1993). In addition, social capital generates understanding, compassion, trust and an inclusive concept of community (Etzioni, 1991; Peck, 2010) Thus, it can be concluded that social capital in construct upon trust and moral behaviors (Wilson, 1997).

In the literature review, many academicians emphasized a positive relationship between social capital and ethics (Adler \& Kwon, 2002; Ayios, Jeurissen \& Spence, 2010; Brehm \& Rahn, 1997). Hence, in this paper from the existing literature findings, we hypothesized that there is a positive relationship do exist between social capital and ethics.

\section{Methodology}

\subsection{Study Design and Sample}


The research was examined on two types of hospital, which are public and private hospitals, located in Diyarbakır/Turkey. Questionnaires were delivered stratified randomly according to their number of personnel. Total of 363 survey forms were collected and 24 surveys were excluded from the analysis due to missing data. Thus, exactly 339 complete forms were evaluated for further analysis. All data was collected in 2014, and the permissions for this survey was taken from University of Dicle's Ethics Committee (IRB)

\subsection{The Survey Instrument}

The survey instrument consisted of questions derived from the literature. There were 15 questions in social capital, and 20 questions in ethics. There was also a demographic information section in the instrument.

a) Demographic Information: Information about the demographic characteristics of the participants was collected, covering their age, gender, education level, marital status, and hospital worked in, and rank.

b) Social Capital Scale: Nahapiet and Ghoshal (1998) specify three dimensions of social capital: first, the structural dimension concerns the extent to which individuals within an organization are connected with each other; second, the relational dimension involves the quality of the connections between individuals within an organization; and, finally, the cognitive dimension focuses on whether individuals share a common language, interpretation, or understanding. The scale developed by Nahapiet and Ghoshal (1998) has been used in numerous studies and these have confirmed its validity and reliability as a measure of relational social capital, cognitive social capital and structural social capital. This scale was adapted to Turkish by Sahin (2010). A five-point Likert scale was used for each of the 15 questions, scored from 1 to 5 where the number (1) means Strongly disagree, (2) Disagree, (3) Not sure, (4) Agree, and (5) Strongly agree. The five-point Likert scale was again used for all these questions. The Cronbach's alpha score is .85. Kolmogrov simirnov ( $p>.05)$ result indicates that it has a normal distribution.

c) Ethics Scale: Forsyth translated this scale, (1980) and also adapted to Turkish language, to measure the employees' perceptions. The scale was based on 20 questions. A five-point Likert scale was used for each of the 20 questions. It was scored from 1 to 5 where the number indicates (1) Strongly disagree, (2) Disagree, (3) Not sure, (4) Agree, (5) Strongly agree. The Cronbach's alpha score was .85. Kolmogrov Simirnov ( $>.05)$ result indicates that the data has a normal distribution. In order to increase validity two items excluded from the analysis

\subsection{Results}

The distribution of the respondents over the demographic variables is presented in Table-1

Table 1. Demographic Variables 
Public Hospital

Variable

Frequency (\%)

$n=258$
Private Hospital

Frequency (\%)

$n=81$

Gender

Male

$123 \quad(47.7)$

$42 \quad(51.9)$

Female

$134 \quad(51.9)$

$37 \quad(45.7)$

Age

20-30

$146 \quad(56.6)$

$37 \quad(45.7)$

$31-40$

$79 \quad$ (30.6)

$30 \quad(37.0)$

41-50

$27 \quad(10.5)$

$12(14.8)$

$50+$

3

(2.3)

$2 \quad(2.5)$

Marital Status

Married

$152 \quad(58.9)$

$41 \quad(50.6)$

Unmarried

$103 \quad(39.9)$

$40 \quad(49.4)$

Education Level

High school

$60 \quad$ (23.3)

18

(22.2)

University

$197 \quad(76.4)$

$63 \quad(77.8)$

Job

Doctor

$68 \quad(26.4)$

27

Nurse

$72 \quad$ (27.9)

$34 \quad(42.0)$

Technician

$118 \quad(45.7)$

$17 \quad(21.0)$ 
Table 2. Levels of Social Capital and Ethics

\begin{tabular}{lllll}
\hline Variables & Minimum & Maximum & Mean & Standard Deviation \\
\hline Ethics & 31 & 84 & 63.3 & 9.9 \\
Social Capital & 15.00 & 75 & 52.3 & 9.5 \\
\hline
\end{tabular}

According to Table 2 results, we found that employee's ethic level is 63.3 and social capital perception level is 52.3. Thus employee's ethic and social capital perception levels are higher than mean. In addition, from the correlation analyses, it was found that correlation between social capital and ethics is significant $(r=.32 ; \mathrm{p}<.001)$. Furthermore, some analyses for demographics indicate that;

- Ethics scores of nurses are higher than doctors (F: $5.42 ; \mathrm{p}<.01)$

- Social capital scores of technicians are lower than nurses and doctors (F: 4.14, $\mathrm{p}<.05)$

- Social capital scores of employees graduate from high school are lower than employees graduate from university $(\mathrm{F}: 3,45 ; \mathrm{p}<.05)$

- Ethics score of females are higher than males (t:2,9, $\mathrm{p}<.01)$

- Ethics score of employees working private hospital are higher than employees working government hospital (t: 5,17, $\mathrm{p}<.001)$.

\section{Discussion and Conclusion}

In this study, we examined the relationship between ethics and social capital. We have taken to the consideration of the term of ethics in view of the latest ethical scandals (i.e. Enron, Dupont, etc.). Also, we put the social capital concept into the model. Nowadays, social capital is recognized as a major determinant of a community's wealth and prosperity. It does not require any natural resources, machines or paid labour. As indicated by Wilson (1997) successfully builded social capital will be the best indicator for prosperity and adaptability in the coming century. Thus, we thought that the concept of social capital will be related to the concept of ethics.

The results indicated that there is a significant positive relationship between social capital and ethics. We also found that nurses reported more scores on ethics than doctors, and employees working at private sector reported more ethical scores than government employees. The results have been found to be parallel to the literature findings. First, it has been evidenced that empirical findings indicate the positive relationship between ethics and social capital (Illingworth, 2012; Ivanova, 2007; Pastoriza et al., 2009).

As in the example of this study, other studies also indicated that nurses' ethics perceptions were found to be higher than doctors and technicians (Chaves and Massarollo, 2009). On this 
issue, Gramelspacher et al. (1986) found that there was a significant variation within these each group about how often they perceived ethical problems. Furthermore, Oberle and Hughes (2001) emphasized that ethical perception differences by nurses and doctors occur according to the decision making processes. They indicated that the key difference was that doctors were thought to be responsible for making decisions and nurses must obey according to these decisions. In this manner, we also think that occupational cultures, hierarchical processes between doctors and nurses, scarce resources, and daily interactions between these groups may emerge as common themes.

From a social role perspective (Eagly, 1987), men and women differ in their social behavior according to their gender. In this study, we found that women were reported higher levels of ethical perception than men. Parallel to this, Schminke and Ambrose (1997) emphasized that men and women differ in both business and nonbusiness settings that women were reported better predictors of both sex's likely ethical models. In contrary, McCabe et al. (2006) found no significant differences between men and women in their ethical perceptions. Furhermore, in this study we also found that employees working at private sector reported more ethical scores than government employees. On this issue, a study examined by Fox et al. (2007) showed parallel findings.

\section{Strengths and Weaknesses}

In this study, we used two important issues and their relationship according to the latest social and organizational context. First, we used the term of ethics. Because, ethical scandals have shown that this concept has to be taken to the consideration elaborately by academicians and practitioners. Second, we used the term social capital, because latest papers mostly discussed the importance of social capital as a major determinant of a community's wealth and prosperity. Furthermore, we collected the data from private and public hospitals in order to show the perception differences between these. Finally, we think that this study has the ability to contribute to the existing ethics literature by examining the relationship between ethics and social capital with quantitative data analysis.

This study also has some weaknesses. First, as in the example of most social and organizational behavior studies, in this study we gathered data from employees' self, and did not use a longitudinal survey in order to decrease common method variance as suggested by Podsakoff et al. (2012). Second, we collected data from a location in Turkey. Thus, the results cannot be generalized to other cultures. Third, we used only two variables in our model. Other studies should strength this model according to the existing literature by adding new mediator/moderator variables. Furthermore, future studies should gather longitudinal data in order to minimize common method variance problem.

In conclusion, this study showed a positive relationship between ethics perception and social capital. The data also revealed some significant demographic differences between and within the variables according to the parallel literature findings.

\section{References}


Adler, P. S., \& Kwon, S. W. (2002). Social capital: Prospects for a new concept. Academy of Management Review, 27(1), 17-40.

Ayios, A., Jeurissen, R., \& Spence, L. J. (2010). Social Capital: A review from an ethics perspective, Brunel University. Brunel Business School Research Papers. Retrieved from http://bura.brunel.ac.uk/handle/2438/4432

Bandman, E., \& Bandman, B. (2002). Nursing Ethics Through the Life Span (4th ed.). Prentice Hall, Upper Saddle River, NJ.

Bandura, A. (1977). Social learning theory. McClelland

Brehm, J., \& Rahn, W. (1997). Individual-level evidence for the causes and consequences of social capital. American Journal of Political Science, 999-1023. http://dx.doi.org/10.2307/2111684

Chaves, A. A. B., \& Massarollo, M. C. K. B. (2009). Perception of nurses about ethical dilemmas related to terminal patients in intensive care units. Revista da Escola de Enfermagem da USP, 43(1), 30-36. http://dx.doi.org/10.1590/S0080-62342009000100004

Clarke, A. C. (1991). Nurses as role models and health educators. Journal of Advanced Nursing, 16(10), 1178-1184. http://dx.doi.org/10.1111/j.1365-2648.1991.tb01526.x

Crane, A. (1999). Are you ethical? Please tick ye sor no on researching ethics in business organizations. Journal of Business Ethics, 20(3), 237-248. http://dx.doi.org/10.1023/A:1005817414241

Demirtas, O. (2015). Ethical leadership influence at organizations: Evidence from the field. Journal of Business Ethics, 126(2), 273-284. http://dx.doi.org/10.1007/s10551-013-1950-5

Eagly, A. H. (1987). Sex differences in social behavior: A social-role analysis. Hillsdale, NJ: Lawrence Earlbaum Associates.

Etzioni, A. (1991). A responsive society: Collected essays on guiding deliberate social change. Jossey-Bass.

Forsyth, D. R. (1980). A taxonomy of ethical ideologies. Journal of Personality and Social psychology, 39(1), 175. http://dx.doi.org/10.1037/0022-3514.39.1.175

Fox, E., Myers, S., \& Pearlman, R. A. (2007). Ethics consultation in United States hospitals: a national survey. The American Journal of Bioethics, 7(2), 13-25. http://dx.doi.org/10.1080/15265160601109085

Gramelspacher, G. P., Howell, J. D., \& Young, M. J. (1986). Perceptions of ethical problems by nurses and doctors. Archives of Internal Medicine, 146(3), 577-578. http://dx.doi.org/10.1001/archinte.1986.00360150227027

Illingworth, P. (2012). Ethics and social capital for global well-being. International Review of Economics, 59(4), 389-407. http://dx.doi.org/10.1007/s12232-012-0160-2 
Ivanova, Y. V. (2007). Ethics in an unethical environment or absence of ethics?. International Journal of Emerging Markets, 2(1), 84-91. http://dx.doi.org/10.1108/17468800710718912

Joseph, J., \& Deshpande, S. P. (1997). The impact of ethical climate on job satisfaction of nurses. Health Care Management Review, 22(1), 76-81. http://dx.doi.org/10.1097/00004010-199701000-00010

MacDonald, H. (2007). Relational ethics and advocacy in nursing: literature review. Journal of advanced nursing, 57(2), 119-126. http://dx.doi.org/10.1111/j.1365-2648.2006.04063.x

McCabe, A. C., Ingram, R., \& Dato-on, M. C. (2006). The business of ethics and gender. Journal of Business Ethics, 64(2), 101-116. http://dx.doi.org/10.1007/s10551-005-3327-x

Nahapiet, J., \& Ghoshal, S. (1998). Social Capital, Intellectual Capital and the Organizational Advantage. Academy of Management Review, 23(2), 242-266.

Oberle, K., \& Hughes, D. (2001). Doctors' and nurses' perceptions of ethical problems in end- of-life decisions. Journal of Advanced Nursing, 33(6), 707-715. http://dx.doi.org/10.1046/j.1365-2648.2001.01710.x

Olson, L. (1994). Ethical climate in health care organizations. International Nursing Review, 42(3), 85-90.

Paldam, M. (2000). Social capital: one or many? Definition and measurement. Journal of Economic Surveys, 14(5), 629-653. http://dx.doi.org/10.1111/1467-6419.00127

Pastoriza, D., Ariño, M. A., \& Ricart, J. E. (2009). Creating an ethical work context: A pathway to generate social capital in the firm. Journal of Business Ethics, 88(3), 477-489. http://dx.doi.org/10.1007/s10551-009-0121-1

Peck, M. S. (2010). The different drum: Community making and peace. Simon and Schuster.

Podsakoff, P. M., MacKenzie, S. B., \& Podsakoff, N. P. (2012). Sources of method bias in social science research and recommendations on how to control it. Annual Review of Psychology, 63, 539-569. http://dx.doi.org/10.1146/annurev-psych-120710-100452

Putnam, R. (2013). The prosperous community: social capital and public life. The American Prospect, 13.

Richardson, A., \& Storr, J. (2010). Patient safety: a literative review on the impact of nursing empowerment, leadership and collaboration. International Nursing Review, 57(1), 12-21. http://dx.doi.org/10.1111/j.1466-7657.2009.00757.x

Schminke, M., \& Ambrose, M. L. (1997). Asymmetric perceptions of ethical frameworks of men and women in business and nonbusiness settings. Journal of Business Ethics, 16(7), 719-729. http://dx.doi.org/10.1023/A:1017953626566 


\section{Macrothink}

Spence, L. J., \& Rutherfoord, R. (2003). Small business and empirical perspectives in business ethics: Editorial. Journal of Business Ethics, 47(1), 1-5. http://dx.doi.org/10.1023/A:1026205109290

Spence, L. J., Jeurissen, R., \& Rutherfoord, R. (2000). Small business and the environment in the UK and the Netherlands: Toward stakeholder cooperation. Business Ethics Quarterly, 10(4), 945-965. http://dx.doi.org/10.2307/3857841

Şahin, I. (2010). Organizational social capital and perceived performance of drug law enforcement departments: a case study in Turkey University of Central Florida, Orlando, FL (unpublished dissertation).

Tuckett, A. G. (2005). Residents' rights and nurses' ethics in the Australian nursing home. International nursing review, 219-224. http://dx.doi.org/10.1111/j.1466-7657.2005.00429.x

Wilson, P. A. (1997). Building social capital: a learning agenda for the twenty- 1st century. Urban studies, 34(5-6), 745-760. http://dx.doi.org/10.1080/0042098975808

\section{Copyright Disclaimer}

Copyright for this article is retained by the author(s), with first publication rights granted to the journal.

This is an open-access article distributed under the terms and conditions of the Creative Commons Attribution license (http://creativecommons.org/licenses/by/3.0/). 